\title{
London in Love
}

\author{
Tzu Yu Allison Lin
}

Gaziantep University, Gaziantep, Turkey

\begin{abstract}
In this paper, I read several literary texts, in order to demonstrate the relation between the viewing subject and the gazed object, in terms of love, illusion, and and aesthetic ecstasy. Walter Benjamin's untitled poem illuminates love and blessing through artistic images, as in Giorgio de Chirico’s painting, The Song of Love (1914). Love in London is somehow a dream-like image—a surreal illusion of love, which stays in the viewer's mind as a poem of colours, representing eternity. Virginia Woolf's Night and Day says it better, when Mary walks into the British Museum and gazes at the Elgin Marbles, thinking how much she is in love with Ralph. John Keats' “On Seeing the Elgin Marbles" also depicts the way in which a gaze of love could be an eternal moment of aesthetic ecstasy.

Keywords: love, aesthetic ecstasy, London, image, illustration
\end{abstract}

\section{Introduction}

Love can be defined in various terms, in different conditions and contexts. When one is alone, love can be seen as a desire. To be alone with one's self somehow is a perfect way to possess the loved object, as one can manipulate the love relation within one's own mind, as the reader can see in Walter Benjamin's note-like poem. In London, Virginia Woolf's character Mary, in Night and Day, has her love secret unfolded when seeing the Elgin marbles in the British Museum. Through the gaze, Mary constructs a surreal situation, which goes beyond her present space and time, imaging Ralph as her guardian, who is able to love her in return. In Keats' poem, readers can see that the whole experience of gazing at the Elgin marbles turns to be a sense of sympathizing love, for the mortality of one's own physical being, and the limitation of its relation with the others.

\section{Love in Imagination}

Let's begin with a poem by Benjamin:

When I begin a song

It sticks

And if I become aware of you

It is an illusion

And thus love wanted you

Humble and small

So that I win you

With being alone

Tzu Yu Allison Lin, doctor, assistant professor, Department of Foreign Language Education, Faculty of Education, Gaziantep University. 
Therefore you slipped from me

Until I learnt

Only flawless petitions

Betray nature

And only enraptured steps

The trace.

blessed. (Marx, 2007, p. 67)

I am fascinated by this little note-like poem, not only because of its neatness in the use of words, but also the richness of its meanings. The narrator sings a song to a lover, knowing that this feeling of love creates an image of the lover in the narrator's mind. Since the narrator cannot physically be with his or her lover, the narrator comes to focus on seeing the image of the lover, as if he or she "win[s]" the lover, by even only thinking about that person. However, the lover's image is very much unstable. It is only a changeable illusion, existing in the narrator's mind, which does not have a certain form. It is always slipping away. The narrator has to trace the illusion of the lover, as it is "[b]etray nature" to be in love with someone like this. For the narrator, to have the illusion of being in love is as real as eternity—it is even "blessed".

In Giorgio de Chirico's painting, The Song of Love (1914), he depicts exactly such a surreal illusion of love, which stays in the viewer's mind as a poem of colours, representing eternity. As in a dream-like illusion, each visual object is not directly connected to another, as if they were picked up randomly: The little white cloud is hanging on the blue sky; on the wall of the building, there are a big head sculpture and a leather glove. The green ball stopped moving. Each visual object has a ridiculous size, which cannot be measured by real terms. All of the visual objects exist in the same space of time, and it looks like they will be there forever. It does not matter which one comes first, to create and to compose the song of love.

\section{Impossible Love}

Love is a feeling as real as eternity, as one can see in Benjamin's poem. Love can also be as painful and unbearable, as a physical movement or a practice, as in one's "soulless travels" on the road:

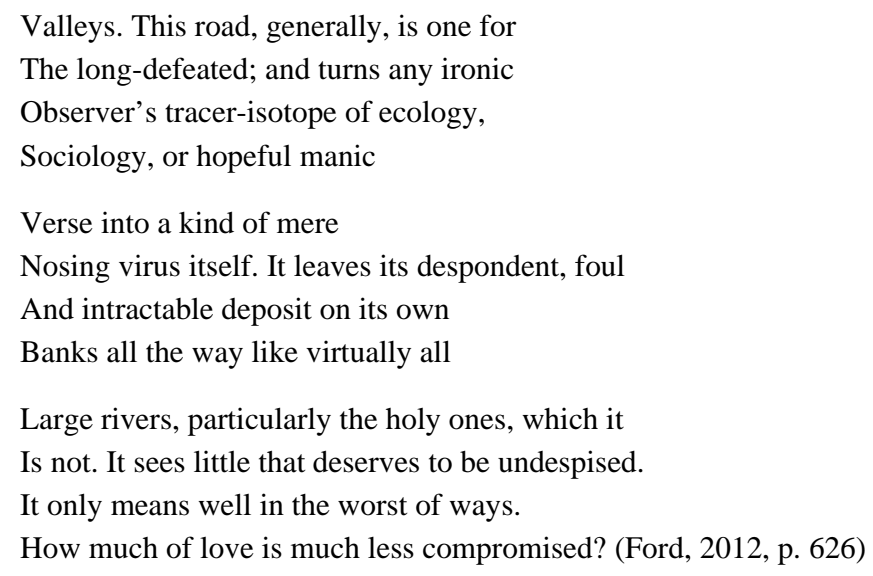

As Alan Brownjohn's narrator asks in the poem, “A 202”, "How much of love is much less compromised”, as one keeps seeing and enduring the very "coarse road” (Ford, 2012, pp. 625-26) across southeast London. This road, A202, as changeless as an "exhausted Grey zigzag of stubborn” (Ford, 2012, p. 625), belongs to the traveler 
himself. The road itself, even it looks like as if "soulless" (Ford, 2012, p. 626) as it could be, is having "no clear attitude" toward the traveler, because the traveler's mood is a complex, specifically on "Monday mornings in town” (Ford, 2012, p. 625).

In Woolf's novel Night and Day, Mary is depicted as a character, who turns aesthetic works of art into an imaginary love relation with Ralph, through her gaze at the Elgin marbles in the British Museum. Mary's gaze seems to empower the works of art, as they externalise her "some wave of exaltation and emotion" (Woolf, 1992, p. 65). Works of art, in Woolf's novel, do not express something "purely aesthetic” (Woolf, 1992, p. 65), as they are externalisation of a character through artistic "shapes".

Mary's emotion were not purely aesthetic, because, after she had gazed at the Ulysses for a minute or two, she began to think about Ralph Denham. So secure did she feel with these silent shapes that she almost yielded to an impulse to say "I am in love with you" aloud. The presence of this immense and enduring beauty made her almost alarmingly conscious of her desire, and at the same time proud of a feeling which did not display anything like the same proportions when she was going about her daily work. (Woolf, 1992, pp. 65-66)

Through Mary, Woolf's writing comes to show that the idea of Beauty is indeed, an impression of one' own emotion. Mary's emotion does not reveal the aesthetic value of a work of art. Her way of seeing does not concern how beautiful the work of art is, or, its artistic techniques. Mary's emotion of love illuminates C. Lewis Hind's aesthetic theory. When Hind saw the Assyrian Winged Bulls, he noticed not the work of art itself, but his own feelings - that "something more", both "strange and stimulating”, transforming "mere technique into mysticism" (Hind, 1911, pp. 88-91). Mary's visual experience in the British Museum particularly depicts her "aesthetic ecstasy” (Bell, 1947, p. 37), coming to show her realization of her desire and her love. Her way of seeing is a very personal, as if the winged Assyrian bulls and the Elgin Marbles would take her to an epic journey of love.

Here is Keats' poetic expression of aesthetic emotions, focusing on the Elgin Marbles:

On seeing the Elgin Marbles (by John Keats)

My spirit is too weak-mortality

Weights heavily on me like unwilling sleep;

And each imagined pinnacle and steep

Of godlike hardship tells me I must die

Like a sick eagle looking at the sky.

Yet 'tis a gentle luxury to weep

That I have not the cloudy winds to keep

Fresh for the opening of the morning's eye.

Such dim-conceivèd glories of the brain

Bring round the heart an undescribable feud:

So do these wonders a most dizzy pain,

That mingles Grecian grandeur with the rude

Wasting of old Time, with a billowy main,

A sun, a shadow of a magnitude. (Ford, 2012, p. 364)

According to Clarke Olney, Keats” “On Seeing the Elgin Marbles”

were the immediate results of a visit to the British Museum under Haydon’s guidance. On this visit, if one may trust Haydon's later recollection, the two enthusiasts were accompanied by John Hamilton Reynolds. The marbles made a profound impression upon Keats; and with Haydon as his guide it is little wonder, for he, better perhaps than any man in London, loved the marbles and had mastered their meaning. (Olney, 1934, p. 262) 
Between 1817 and 1818, Keats and the painter Benjamin Robert Haydon began their "intimate friendship" (Olney, 1934, p. 260), which had a great impact on Keats' poetry. "Haydon was thirty-one, Keats ten years his junior: both were young and passionately intense in their love for beauty” (Olney, 1934, p. 261). Both the young artist's and the young poet's (Keats was "virtually unknown”) love for artistic creation makes them think about each other as "truly one of those, / Whose sense discerns the loveliness of things" (Olney,1934, p. 260).

Haydon believes that art should be the "powerful", the "grand", in order to achieve the "highest", the "most 'sublime’ themes” (Olney, 1934, p. 274). This aesthetic ideology somehow does not necessarily represent Keats' own poetic senses, as his “On Seeing the Elgin Marbles” would show. Although "sorrow” and "hopeless love” (Olney, 1934, p. 275) in Keats' poem are not exactly the emotions that Haydon needs, for his grand "historical or religious themes" (Olney, 1934, p. 275), the intense friendship between two artists somehow becomes immortal, as Beauty and the intense aesthetic emotions the viewer's—-which is “a gentle luxury” to cry (Ford, 2012, p. 364).

\section{Conclusion}

Through literary texts, readers are able to identify words which represent feelings of love. An understanding of love is difficult to achieve, as there is no single way to define love. Words and images are in the same complexity, trying to express the moment of eternity that one feels in love. As one gazes at the work of art, somehow imagination and feeling come together, synthesizing the meaning of love, as a part of experiences in life.

\section{References}

Bell, C. (1947). Art. London: Chatto and Windus.

Ford, M. (2012). London: A history in verse. Cambridge: Harvard University Press.

Hind, C. L. (1911). The post-impressionists. London: Methuen.

Marx, U., Schwartz, G., Schwartz M., \& Wizisla, E. (Eds.) (2007). Walter Benjamin’s Archive: Images, Texts, Signs. London: Verso,.

Olney, C. (1934). John Keats and Benjamin Robert Haydon. PMLA, 49(1), 258-275.

Woolf, V. (1992). Night and day. J. Briggs, (Ed.). London: Penguin. 